\title{
Electronic Module With Project Based Learning: Innovation of Digital Learning Product on 4.0 Era
}

Titis Angga Rini, Puri Selfi Cholifah

Universitas Negeri Malang Fakultas IImu Pendidikan

\section{Edcomtech}

Jurnal Kajian

Teknologi Pendidikan

Volume 5, No 2, Oktober 2020

155-161

Submitted 30-11-2019

Accepted 04-05-2019

Corresponding Author

Titis Angga Rini

angga.rini.fip@um.ac.id

OPEN

ACCESS

\begin{abstract}
Digital teaching materials become one of the main needs in the field of education in this 4.0 era. Digital teaching materials continue to be innovated in various forms such as e-modules in learning. Based on this need, this study aims to develop e-modules that are collaborated with PjBL for learning basic skills of learning. The study was conducted with a development research procedure that adapted the Dick \& Carey development model (2015). Development research is carried out with a validation test to the expert and user test to obtain data on the results of the application of the product as appropriate teaching material. The results of the product development show that the collaboration between e-modules and PjBL received a good response from experts and users both educators and students who met the qualifications of appropriate criteria as teaching material. This development is one form of digital product innovation that bridges current and future learning needs for students to skillfully use IT in the digital age in learning as prospective educator.
\end{abstract}

Keywords: e-module, project based learning, digital learning product 


\section{INTRODUCTION}

One of the changes in the education system in the 4.0 era was the digitalization of the learning process. The digitalization of learning is packaged in a network that no longer requires the presence of educators and participants who are more flexible to utilize the potential of space, time and cost (Hold, Erol, Reishinger, \& Shin, 2017). Digitalization which is closely related to technological development gave rise to learning metaphors as a new ecology that emphasizes the transformational and performative nature of its implementation (Saljo, 2010). Transformation and performance require the development of the competence of educators and students to get closer to technology.

The results of observations through search engines are known that there have been many developed various learning management systems that can be accessed publicly or specifically developed by an institution. This fact is consistent with the results of previous studies from that this system facilitates the application of e-learning which is realized in various forms of digital learning materials such as teleconferences, discussion forums, e-questions, e-modules, and others (Alvermann \& Sanders, 2019). This material is a major need that is currently being developed in various forms of learning innovation to optimize the use of IT in the field of education (Yadin \& Or-Bach, 2019).

The needs analysis was carried out on the development of digital teaching materials in elementary school teacher education study programs, State University of Malang, Indonesia. The results of the needs analysis show that not all course material is packaged in the form of digital teaching materials. Submission of courses dominated by group activities and assignments, especially in addressing the limited presence of educators in the classroom. This certainly raises the gap in this 4.0 era, as the results of the study of Henderson, Selwyn, \& Aston (2015) that digital technology became a central element of undergraduate education and related substantial changes to learning experiences in expanding the availability and accessibility of systems (Sweeney \& Moore, 2012).
The gap between IT development and the situation on the ground shows that product innovation is needed in the form of electronic teaching materials that can be integrated into the digital learning process. The development of teaching materials should also meet innovative elements in the context of developing competencies. Innovation plays a major factor in adapting to changes and developments in IT in this 4.0 era in the field of education (Stachová, Papula, Stacho, \& Kohnová, 2019). Innovation on the development of electronic teaching materials will contribute to the increase in the use of IT from both educators and students who will also play a role as educators in the more advanced digitalization era of this century.

In line with the results of the needs analysis that the delivery of courses tends to be carried out in group assignments, project-based learning ( $\mathrm{PjBL}$ ) is considered an appropriate innovation in this research development. $\mathrm{PjBL}$ is known as a motivating learning model (Genc, 2015) and is centered on projects that provide opportunities for students to transfer scientific knowledge in practical activities (Zang, Hansen, \& Andersen, 2016). Based on this, the purpose of this study is to develop digital teaching materials that meet the qualifications of eligibility in terms of validity, applicability, practicality, presentation, and readability as teaching materials.

Thee-module product was developed based on a project for independent or group learning in a blended system. Project assignments are designed periodically to contain learning activities for the deepening of material that has been delivered by educators (Indahwati, Tuasikal, \& Ardha, 2019). This is considered appropriate especially for universities that emphasize the independence of students in learning and building a more comprehensive understanding (Lemoine, Yates, \& Richardson, 2019). Products are designed in such a way as to implement communication skills, collaboration, critical thinking, creativity and innovation by the selection of courses of basic learning skills that are process-oriented and the products of students' mastery of basic skills in teaching. 


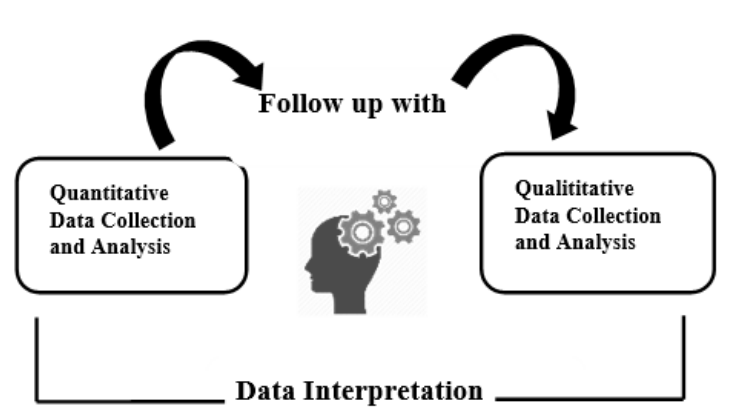

Fig 1. Data Analysis Technique

\section{RESULTS}

This study uses the Dick and Carey development model (2015) as a systematic model for developing teaching materials. This research was carried out in seven stages namely, (a) identification of objectives, (b) material analysis, (c) formulating performance goals, (d) determining products, (f) developing learning materials, (g) designing and implementing formative and summative evaluations through validation and testing, and (h) overall revision of the results of product development. Validation is carried out to material experts and technology experts to determine product eligibility. From the results of expert validation, the product was revised according to expert advice and trialed to the user classically to determine the feasibility of the product in terms of its use.

This research will be carried out in the PGSD S1 Study Program as a population with sample selection using simple random sampling to determine the user subjects of lecturers and students of Basic Skills Learning courses. Besides, this study also involved material and technology, expert lecturers, as product validators. From these research subjects, quantitative and qualitative data will be collected by using questionnaires, interviews, and documentation. The research data were processed in mix methods with quantitative and qualitative descriptive analysis techniques as follows.

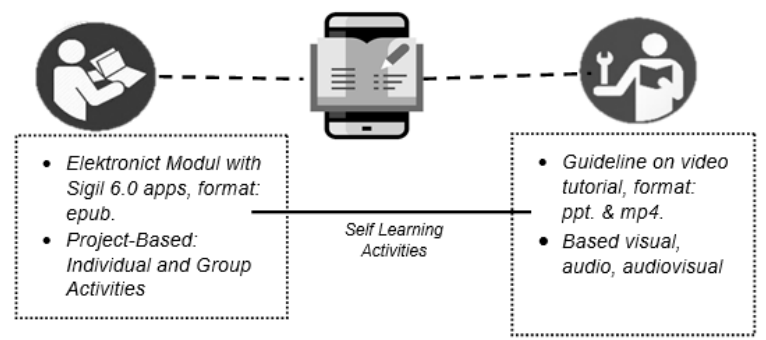

Fig 1. Product Specification
Quantitative descriptive data analysis was performed by presenting the results of the expert validation test results and user tests. From the results of the calculation of these percentage values, the level of product eligibility is determined according to the criteria determined as follows.

Table 1. Validation Results

\begin{tabular}{|l|l|l|}
\hline \multicolumn{1}{|c|}{ Indicator } & Material Expert & $\begin{array}{c}\text { Technology } \\
\text { Expert }\end{array}$ \\
\hline Content & $81,25 \%$ & $81,25 \%$ \\
\hline Practicability & $80 \%$ & $87,5 \%$ \\
\hline Presentation & $93,75 \%$ & $80 \%$ \\
\hline Legibility & $75 \%$ & $78,5 \%$ \\
\hline \multicolumn{1}{|c|}{ Average } & $82,5 \%$ & $81,82 \%$ \\
\hline Qualification & Good, feasible & Good, feasible \\
\hline
\end{tabular}

The results of product validation show that the product is in a decent qualification at a percentage level of $82.5 \%$ with good and proper qualifications for e-modules, and a percentage level of $81.82 \%$ with good qualifications and appropriate for guidance. From the results of this expert validation, product revisions include a more concise material presentation and cutting the duration of the video guide specified for students and educators in their operation. The product is then tested to users (educators and students) with the following results.

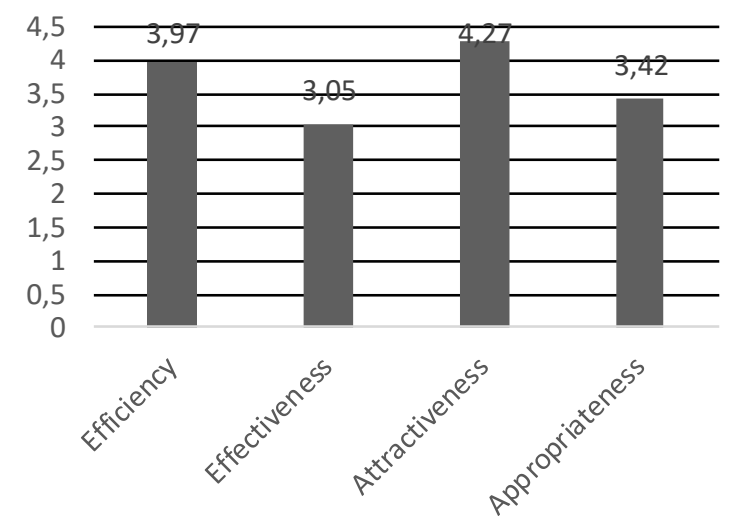

Fig 2. Product Test Results

User test results indicate that the average respondent stated that the product has a good enough qualification from the range of scores 1-5, not good / feasible-very good/ feasible including efficiency, effectiveness, interest, and applicability. This data is also deepened with the results of field notes and 
interviews during user tests. Field notes show that, on average, students can use e-modules well through their respective smartphones or PCs. E-modules that have been equipped with activity guides help students understand the assignment and deepen the material especially in accessing learning resources on the links that have been provided. The guide in the form of a video tutorial complements the use of e-modules if integrated with the e-learning system, covering operational procedures for content and access that can be followed by educators and students. There are some obstacles especially in the duration that was originally too long so that improvements were made to cut the duration within \pm 10 minutes of the show.

Besides, testing the application of products in learning shows that the use of e-module products can be applied well in learning the basic skills learning courses. Electronic modules contain four topics starting in understanding the concept of skills, designing learning activities, simulating basic learning skills, and academic supervision. On the first topic, students apply critical thinking skills to deepen the material about the concepts and implementation of basic teaching skills in ideal conditions with conditions in the field. From mastering this concept, students then design learning activities that implement basic teaching skills to be simulated at the next meeting. During this learning process classes are held offline-online for discussion and assignment. From the results of the documentation of the design of learning activities and simulation results, it appears that students are better at mastering material and can simulate basic learning skills better.

Interview data from respondents stated that digital teaching materials in the form of e-modules help students and educators in learning online. This efficient and effective digital teaching material helps when educators are unable to attend because it has been accompanied by a summary of material and clear learning activities. Guides in the form of video tutorials are very helpful for e-module operations, given the limitations of mastering the latest application features. Learners and educators state that the format of this product is more practical to use because videos, links, and other material in e-modules can be presented in one package. Although from its application, for certain types of devices it is necessary to update supporting features so that device support is needed.

\section{DISSCUSIONS}

Products in the form of e-modules and video tutorials show the results of developing good digital teaching materials in terms of effectiveness according to the user. This is in line with the results of research from Chen \& Liu (2017) that learning digitally presents a positive effect on the learning outcomes and motivation of students of the current generation. Students are more enthusiastic about learning by utilizing IT and practical things to explore that can be found through digital learning with various types of teaching materials such as in the form of e-modules and video tutorials. These findings indicate that educators as learning designers in addition to paying attention to the types of digital teaching materials, the components of attention and activeness of students really must be considered (Woo, 2014).

Attention and activeness of students will indirectly have an impact on student learning outcomes. This is indicated by the learning outcomes in the form of simulation activities that can be carried out and better mastered bystudents. Attention and activeness become part of students' self-management to collect information independently (Malik, Suryaman, \& Rusmawati, 2019) according to the guidance given in the e-module. Students are required to realize the importance of the learning process in achieving success with or without the presence of educators directly.

The results of product development also show positive responses from users, especially from students in learning about basic learning skills. This response shows the awareness and needs of users of digital developments in the 4.0 century, especially in the academic field (Tanjung, 2019). Most of the participants felt enthusiastic about the development of digital teaching materials which they hoped would be applicable when teaching at school. This need is one of the important visions of 
tertiary institutions to develop curriculum, activities, and student learning materials (Coşkun, Kayıkcı, \& Gençay, 2019).

Also, for students in teacher training programs awareness of the development of digitizing learning becomes one of the competencies for teaching in the future. The digitalization of learning requires that prospective teacher students can operate a variety of learning technologies (McLoughlin \& Lee 2010). This is shown in the presentation of the e-module format which prerequisites the supporting files to be able to operate the features in them properly. In other words, students who can operate e-modules well can be categorized as more capable of operating technology than students who experience difficulties.

In the e-module, the learning process is designed not only to center on educators but also to provide opportunities for students to construct their knowledge and skills based on independent learning. Innovations in this e-module can be pursued gradually in the hope that participants can better develop their knowledge and skills in learning about basic teaching skills in the era of industry 4.0 (Guo, 2015). This is by the results of previous research by Mitchell, et.all (2018) that in learning it is recommended to develop learning features that present many types of knowledge to be taken gradually over a certain period.

The stages of learning in the e-module lead to the process of independent learning and awareness of students to learn on an ongoing basis. The process begins with an understanding of concepts, design, application or practice, and evaluation. From this stage, students can reflect on the skills possessed to improve the achievement of learning goals. The results of the learning process will then be clarified and reinforced for assessment from the beginning to the end of the activity (Voogt, Erstad, Dede, \& Mishra, 2013). Assessment is not only intended to determine the achievement of objectives but also to improve the learning process and learning outcomes of students for one semester.
The results of the implementation of e-modules based on Project Based Learning during the trial show that both independent and group activities can be well simulated. In practical subjects, such as basic learning skills, learning activities need to be centered on students to practice individually or in groups. For prospective teachers, this exercise will affect work commitments which in reality for prospective teachers the work commitments they have will be higher than those given training (Klassen \& Chiu, 2011). The e-module product developed by this learning activity is realized through concept understanding activities, designing learning activities, and teaching skills simulation.

Collaboration with the Project-Based Learning model also shows positive results because the basis of individual and group activities activates the learning process of students. The activeness of students in Iwamoto, Hargis, and Vuong's research (2016) has been tested to be more effective than the experimental group with traditional class designs. Through project activities, educators can propose more practical activities and place them in specific learning contexts. Especially in the results of Garcia's research (2016) which shows that the application of $\mathrm{PjBL}$ in the context of digital learning is to encourage meaningful learning.

Meaningful learning is shown by the awareness and involvement of students in completing project tasks, especially in practical teaching assignments. This is due to students being able to more actively apply their knowledge to confirmed face to face (Lee, Huh, \& Reigeluth, 2015). It is this activity that needs to be considered that on a project basis, educators continue to monitor the student's learning process. This behavior according to the results of Armanta, Mustaji, \& Suryaman's (2019) research on the application of Project-Based Learning in learning will have a positive effect on student learning outcomes. Influence is aimed through the trace of the process and learning outcomes of students relating to learning activities one whether learning activities have increased or decreased. 


\section{CONCLUSION}

From the results of research on the development of e-modules with PjBL, the results show that the product achieves good qualifications to be used as teaching material. Achievement of product feasibility is demonstrated by the results of expert tests that meet the criteria of content validity, practicality, presentation, and readability. This is also supported by the product user test results both from educators and participants achieve good qualifications according to the criteria of efficiency, effectiveness, interest, and applicability of the product. Overall the product meets the quality criteria that have been determined and can be operated in a network-based IT system both offline and online according to the digitization criteria of learning in the 4.0 century. In its application, the PjBL basis shows that the product can be used as an independent and group teaching material for the deepening and assignment of the material being studied. Projects in e-modules direct students to be more actively involved in the process and monitor the results of their learning.

Based on the results of this study it is recommended for academics especially university lecturers to develop products in the form of digital teaching materials in the form of e-modules or other that have the qualifications and are tested in terms of experts and users to meet educational needs in the 4.0 and future era. Also, the results of this study are suggested to be applied and tested in the design of experiments to determine the effect of e-modules on the process and learning outcomes of students.

\section{REFERENCES}

Alvermann, D. E., \& Sanders, R. K. (2019). Adolescent literacy in a digital world. The International Encyclopedia Of Media Literacy, 1-6. DOI: 10.1002/9781118978238.ieml0005.

Armanta, A. Y., Mustaji, M., \& Suryaman, S. (2019). The Influence of the Problem Based Learning and Attitudess Towards Learning Outcomes for Mathematics. Edcomtech Jurnal Kajian Teknologi Pendidikan, 4(1), 1-7. DOI: 10.17977/um039v4i12019p001.
Coşkun, S., Kayıkcı, Y., \& Gençay, E. 2019. Adapting Engineering Education to Industry 4.0 Journal of Vision. Technologies, 7(1), 10. DOI: 10.3390/ technologies7010010.

Dick, W.C, Carey, J. O. 2015. The Systematic Design of Instruction. New Jersey: Pearson Ltd.

García, C. 2016. Project-Based Learning in Virtual Groups-Collaboration And Learning Outcomes In A Virtual Training Course For Teachers. Procedia-Social and Behavioral Sciences, 228, 100-105. DOI: 10.1016/j.sbspro.2016.07.015.

Genc, M. (2015). The project-based learning approach in environmental education. International Research in Geographical and Environmental Education, 24(2), 105-117.DOI: 10.1080/10382046.2014.993169.

Guo, Q. 2015. Learning in a Mixed Reality System in the Context of ,Industrie 4.0 '. Journal of Technical Education (JOTED), $3(2)$.

Hold, P., Erol, S., Reisinger, G., \& Shin, W. 2017. Planning dan Evaluation of Digital Assistance Systems. Procedia Manufacturing, 9, 143-150. DOI: 10.1016/j.promfg.2017.04.024.

Indahwati, N., Tuasikal, A. R. S., \& Al Ardha, M. A. 2019. Developing Project Based Learning $(\mathrm{PBL})$ as a teaching Strategy in Physical Education for Preservice Physical Education Teacher. In 1st International Conference on Education Social Sciences and Humanities (Atlantis Press), DOI: 10.2991/icesshum-19.2019.79.

Iwamoto, D. H., Hargis, J., \& Vuong, K. 2016. The Effect Of Project-Based Learning On Student Performance: An Action Research Study. International Journal for the Scholarship of Technology Enhanced Learning, 1(1), 24-42.

Klassen, R. M., \& Chiu, M. M. (2011). The occupational commitment and intention to quit of practicing and pre-service teachers: Influence of self-efficacy, job stress, and teaching context. Contemporary Educational Psychology, 36(2), 114-129. DOI: 10.1016/j.cedpsych.2011.01.002. 
Lee, D., Huh, Y., \& Reigeluth, C. M. (2015). Collaboration, intragroup conflict, and social skills in project-based learning. Instructional Science, 43(5), 561-590.

Lemoine, P. A., Yates, M., \& Richardson, M. D. (2019). Technology and learning: preparing teachers for the future. In Pre-Service and In-Service Teacher Education: Concepts, Methodologies, Tools, and Applications (IGI Global), 2164-2182. DOI: 10.4018/978-1-52257305-0.ch101.

Lin, M. H., Chen, H. C., \& Liu, K. S. 2017. A Study of The Effects of Digital Learning on Learning Motivation And Learning Outcome. Eurasia Journal of Mathematics, Science and Technology Education, 13(7), 3553-3564. DOI: 10.12973/eurasia.2017.00744a.

Malik, A., Suryaman, S., \& Rusmawati, R. D. (2019). Pengaruh Pengelolaan Diri Siswa Dan Karakter Guru terhadap Prestasi Belajar Siswa Kelas X SMK Satya Widya Surabaya dan SMK Tri Tunggal Surabaya. Edcomtech Jurnal Kajian Teknologi Pendidikan, 4(2), 143-152. DOI: 10.17977/um039v4i22019p143.

McLoughlin, C., \& Lee, M. J. 2010. Developing an Online Community to Promote Engagement and Professional Learning For Pre-Service Teachers Using Social Software Tools. Journal of Cases on Information Technology (JCIT), 12(1), 17-30, DOI 10.4018/jcit.2010010102.

Mitchell, T., Cohen, W., Hruschka, E., et.all. 2018. Never-Ending Learning. Journal of Communications of The ACM, 61(5), 103-115. DOI: 10.1145/3191513.

Saljo, R. 2010. Digital Tools and Challenges to Institutonal Traditions of Learning:Technologies, Social Memory, and The Performative Nature of Learning. Journal of Computer Assisted Learning, 26, 1. DOI: 10.1111/j.13652729.2009.00341.x.
Stachová, K., Papula, J., Stacho, Z., \& Kohnová, L. 2019. External partnerships in employee education and development as the key to facing industry 4.0 challenges. Sustainability, 11(2), 345. DOI: $10.3390 /$ su11020345.

Sweeney, P., \& Moore, C. 2012. Mobile apps for learning vocabulary: Categories, evaluation and design criteria for teachers and developers. International Journal of Computer-Assisted Language Learning and Teaching (IJCALLT), 2(4), 1-16. DOI: 10.4018/ijcallt.2012100101.

Tanjung, R. F. 2019. Answering the Challenge of Industrial Revolution 4.0 Through Improved Skills Use of Technology College. International Journal for Educational and Vocational Studies, 1(1), 11-14. DOI: 10.29103/ijevs. v1i1.1374.

Voogt, J., Erstad, O., Dede, C., \& Mishra, P. 2013. Challenges to learning and schooling in the digital networked world of the 21st century. Journal of Computer Assisted Learning, 29(5), 403-413, doi: 10.1111/jcal.12029.

Woo, J. C. 2014. Digital Game-Based Learning Supports Student Motivation, Cognitive Success, And Performance Outcomes. Journal of Educational Technology \& Society, 17(3), 291-307.

Yadin, A., \& Or-Bach, R. 2019. The Importance Of Emphasizing Individual Learning In The "Collaborative Learning Era". Journal of Information Systems Education, 21(2), 5, form https://aisel. aisnet.org/iise/vol21/iss2/5.

Zhang, Z., Hansen, C. T., \& Andersen, M. A. 2015. Teaching power electronics with a design-oriented, project-based learning method at the Technical University of Denmark. IEEE Transactions on Education, 59(1), 32-38. DOI: 10.1109/ TE.2015.2425574. 